\title{
Dampak Konseling Terhadap Tingkat Kecemasan Klien Dengan Risiko Tinggi HIV AIDS Di Daerah Pariwisata Senggigi Lombok Barat
}

\author{
I Putu Artawan Prayoga ${ }^{1}$, Akhmad Fathoni $^{2}$, Muhammad Sunarto ${ }^{3}$ \\ ${ }^{1}$ Magister Administrasi dan Kebijakan Kesehatan Universitas Qamarul Huda Badaruddin, \\ ${ }^{2,3}$ Politeknik Kesehatan Mataram
}

Email: putuartawan1977@gmail.com¹, akhmadfatoni@gmail.com², $\underline{\text { Msunarto@gmail.com }}$

\begin{abstract}
Individuals with high risk of HIV and AIDS who come to the service center VCT (Voluntary Counseling and Testing) feel worried or anxious that he has contracted HIV so he wants to know about his condition. They are usually worried or anxious about the implications of AIDS itself physically, psychologically, spiritually and socially namely the stigma and discrimination of society. Aim: this study was to determine the effect of counseling on changing anxiety levels of clients at high risk of HIV and AIDS. Methods: The design of this study was pre-experiment with one group pre-post-test design approach because before being given treatment, the client first assessed the level of anxiety, then after being given treatment the level of anxiety was re-examined, whether decreased anxiety level or not. The instrument used in this study was the HARS questionnaire. The instrument used in this study was the HARS questionnaire. The sampling technique used was purposive sampling with 21 samples. Univariate data analysis used is in the form of narration, frequency and percentage distribution tables, and bivariate analysis using parametric data analysis techniques, namely t-test dependent. Result: This study shows that from 21 respondents before and after counseling, they have a difference of 6.19 with a standar deviation of 4.98. The $\mathrm{p}$ value of 0.000 indicates that the value is smaller when comparing the alpha value of $5 \%$ (0.05), meaning that there are differences in anxiety before and after counseling, so it can be concluded that there is an influence of spiritual counseling on the level of anxiety in high risk clients of HIV and AIDS in the area Senggigi medical tourism center. Conclusion: provision of counseling that has been going well in order to be maintained and enhanced by holding professional counselors training regularly and continuously.
\end{abstract}

Keyword : Anxiety, Counseling

\section{PENDAHULUAN}

Human Immunodeficiency Virus

(HIV) dan Acquired Immune Deficiency Syndrome (AIDS) merupakan permasalahan kesehatan yang cukup besar di Indonesia. Selain itu HIV/AIDS merupakan permasalahan kesehatan masyarakat yang sangat penting di beberapa negara dan bahkan memiliki dampak yang bersifat internasional (global). HIV/AIDS terjadi pada setiap periode umur, tidak hanya pada kelompok tertentu tetapi terjadi juga pada dewasa muda dan anak-anak dan juga pada kelompok yang dianggap tidak berisiko ${ }^{(1)}$.

Menurut data Komisi Penanggulangan AIDS Nasional di Indonesia (KPAN) Jumlah kasus terinfeksi HIV/AIDS di Indonesia hingga 2010 mencapai antara 93 ribu hingga 130 ribu kasus, sedangkan tahun 2014 terdapat 501.400 kasus HIV/AIDS $\left(^{2}\right)$.
Berdasarkan data Kemenkes tahun 2012, dari 750 ibu hamil yang melakukan pemeriksaan ante natal di Puskesmas, yang setuju untuk dilakukan pemeriksaan tes HIV hanya $50 \%$ saja. Hal ini terjadi karena kekhawatiran dan rasa cemas yang mereka rasakan jika mereka terinfeksi HIV dampak akan menjadi lebih besar. Kekhawatiran akan hasil tes menyebabkan mereka tidak mau memutuskan untuk dilakukan tes HIV secara sukarela. Begitupun kelompok berisiko, yang memiliki kesadaran untuk melakukan tes HIV secara sukarela hanya $30 \%$ saja dari jumlah prediksi kelompok berisiko $\left({ }^{3}\right)$. Infeksi virus HIV menjadi bagian dari penyakit kronis yang menimbulkan tekanan psikologis yang tinggi dan rasa cemas pada Orang Dengan HIV AIDS (ODHA). Kecemasan sangat berkaitan dengan perasaan yang tidak pasti, tidak berdaya $\left({ }^{4}\right)$. 
Kecemasan yang berlebihan dapat mempunyai dampak yang merugikan pada pikiran serta tubuh bahkan dapat menimbulkan penyakit-penyakit fisik $\left({ }^{5}\right)$.

Menurut Yulianti (2004) dalam Wandira \& Pribadi $\left({ }^{6}\right)$, untuk menghindari dampak dari kecemasan, maka diperlukan adanya suatu pengelolaan kecemasan yang baik. Dalam mengelola kecemasan dapat dilakukan dengan terapi farmakologi yang meliputi penggunaan obat cemas (axiolytic) dan anti depresi (anti depressant), serta terapi nonfarmakologi yang meliputi pendekatan perilaku, pendekatan kognitif, serta relaksasi. Untuk mengurangi kecemasan, sebaiknya orang yang yang terinfeksi HIV/AIDS melakukan problem focused coping (melakukan usaha-usaha yang diarahkan untuk memecahkan masalah), seperti melakukan konseling lanjutan, mencari dan melakukan pengobatan HIV/AIDS (7)

Penelitian yang dilakukan Sugiyanto (8) menjelaskan ada pengaruh yang signifikan dari konseling spiritual perawa tterhadap tingkat kecemasan pada keluarga pasien yang dirawat diruang ICU RSUD Sleman.

Intervensi keperawatan yang dapat diberikan pada klien yang mengalami kecemasan berdasarkan Nursing Intervetion Classification (9) antara lain konseling. Konseling merupakan proses yang berfokus pada kebutuhan, masalah atau perasaan klien melalui komunikasi aktif dua arah, pertukaran pengalaman, pemberian solusi berdasarkan kesepakatan bersama guna menemukan ide untuk meningkatkan atau mendukung koping, pemecahan masalah dan menciptakan hubungan interpersonal yang baik (10).

Mencermati adanya keterkaitan antara kecemasan dan pemahaman tentang HIV maka perlunya memberikan dukungan dan informasi kepada orang yang mempunyai risiko tertular HIV dengan cara memberikan konseling yang disebut dengan Voluntary Conseling and Testing (VCT). Proses konseling termasuk mengevaluasi risiko personal penularan HIV, memfasilitasi pencegahan perilaku yang tidak sehat dan mengevaluasi penyesuaian diri ketika klien menghadapi hasil tes positif (11).

Disinilah peranan konselor dalam memberikan konseling. Proses mengenai seseorang individu yang sedang mengalami masalah (klien) dibantu untuk merasa dan bertingkah laku dalam suasana yang lebih meneyenangkan melalui interaksi dengan seseorang yang tidak bermasalah, menyediakan informasi dan reaksi-reaksi yang merangsang klien untuk mengembangkan tingkah laku yang memungkinkannya berperan secara lebih efektif bagi dirinya sendiri dan lingkungannya $\left({ }^{12}\right)$.

Dari pemikiran diatas penulis tertarik untuk melakukan penelitian tentang pengaruh pemberian konseling terhadap tingkat kecemasan klien risiko tinggi HIV dan AIDS di daerah pariwisata yaitu di Medical Center Senggigi.

\section{METODE PENELITIAN}

Desain penelitian ini adalah pra eksperiment dengan pendekatan one group pre post-test designe karena sebelum diberikan perlakuan, klien dikaji terlebih dahulu tingkat kecemasannya, kemudian setelah diberi perlakuan dikaji kembali tingkat kecemasannya, apakah mengalami penurunan tingkat kecemasan atau tidak. Tekhnik pengambilan sample yang digunakan yakni purposive sampling dengan jumlah sampel sebanyak 21 orang. Analisa data yang digunakan adalah univariat dengan dalam bentuk narasi, tabel distribusi frekuensi dan persentase, serta bivariat menggunakan teknik analisa data parametrik yaitu t-test dependent.

Instrumen yang digunakan dalam penelitian ini adalah kuesioner Hamilton Anxiety Rating Scale (HARS). HARS merupakan pengukuran kecemasan yang didasarkan pada munculnya gejala-gejala individu yang mengalami kecemasan. Instrumen ini telah diuji validas dan reliabilitasnya oleh Fu'ad, Dayal, \& Fuad (13). Hasil uji validitas tiap item pertanyaan $>0,05$ dan nilai reliabilitasnya $0,793>0,6$ sehigga kuesioner ini dapat dinyatakan valid dan reliabel. Interpretasi dari kuesioner ini dikatakan tidak ada kecemasan jika skor $<6$, kecemasan ringan skor 6-14, kecemasan sedang skor $15-27$, kecemasan berat skor 2836 , dan kecemasan berat sekali/panik jika skor $>36$.

Klien yang melakukan kunjungan konseling ke Klinik Medical Center Senggigi 
yang menjadi responden dilihat berdasarkan adanya kecemasan yang dialami. Selanjutnya dilakukan proses skrining responden sesuai dengan kriteria inklusi. Kriteria inklusi dalam penelitian ini adalah klien dengan risiko tinggi HIV dan AIDS, klien yang berusia 18-55 tahun, klien yang bersedia menjadi responden, klien dengan kesadaran baik dan tidak mengalami gangguan jiwa.

Klien bisa baca tulisakan diberikan informed consent selanjutnya akan dilakukan diberikan kuesioner HARS untuk diisi, setelah didapatkan hasilnya maka dilakukan konseling oleh konselor sebanyak 3 kali konseling. Setelah pelaksanaan konseling dilakukan obesrvasi post konseling untuk diukur derajat kecemasannya dengan menggunakan instrumen HARS kembali.

\section{HASIL PENELITIAN}

Karakteristik responden pada penelitian ini meliputi jenis kelamin, umur, pendidikan, dan pekerjaan dapat dilihat pada tabel 1., distribusi responden berdasarkan faktor risiko tinggi HIV dan AIDS dapat dilihat pada tabel 2., sedangkan tingkat kecemasan sebelum dan setelah dilakukan konseling dapt dilihat pada tabel 3. dan 4. berikut ini:

Tabel 1. Distribusi frekuensi data karakteristik responden.

\begin{tabular}{|c|c|c|}
\hline Variabel & Frekuensi & $(\%)$ \\
\hline $\begin{array}{c}\text { Jenis Kelamin } \\
\text { Laki-laki }\end{array}$ & 13 & 61.9 \\
\hline Perempuan & 8 & 38.1 \\
\hline \multicolumn{3}{|l|}{ Umur } \\
\hline 15-20 tahum & 4 & 19 \\
\hline 20-25 tahun & 6 & 28,6 \\
\hline $25-30$ tahum & 7 & 33,3 \\
\hline $30-35$ tahun & 3 & 14.7 \\
\hline$>35$ tahun & 1 & 2.7 \\
\hline \multicolumn{3}{|l|}{ Pendidikan } \\
\hline SD & 6 & 28,6 \\
\hline SMP & 1 & 4,8 \\
\hline SMA & 10 & 47,6 \\
\hline PT & 4 & 19 \\
\hline \multicolumn{3}{|l|}{ Pekerjaan } \\
\hline Kar. Hotel & 8 & 38,1 \\
\hline Buruh & 2 & 9,5 \\
\hline WPS & 4 & 19 \\
\hline Kar. Cafe & 7 & 33,3 \\
\hline
\end{tabular}

Berdasarkan tabel 1. didapatkan bahwa responden terbanyak adalah dengan jenis kelamin laki-laki dengan jumlah 13 orang $(61,9 \%)$, umur responden terbanyak berada pada kelompok umur 25-30 tahun dengan jumlah 7 orang $(33,3 \%)$, tingkat pendidikan responden mayoritas adalah SMA sebanyak 10 orang $(47,60 \%)$, sedangkan mayoritas pekerjaan responden adalah karyawan hotel yaitu 8 orang $(38,1 \%)$.

Tabel 2. Distribusi Responden Berdasarkan Faktor Risiko Tinggi HIV dan AIDS

\section{Risiko Tinggi \\ Jumlah Persentase}

Sex lewat vagina

tanpa kondom,

ejakulasi didalam

5

Sex anal tanpa

kondom, ejakulasi didalam

12

57.14

Tukar menukar jarum suntik dan

\begin{tabular}{ccc} 
semperit (IDUS) & 4 & 19.05 \\
\hline Total & $\mathbf{2 1}$ & $\mathbf{1 0 0}$ \\
\hline
\end{tabular}

Tabel 3. Distribusi Responden Berdasarkan Tingkat Kecemasan Klien Sebelum Konseling

\begin{tabular}{ccc}
\hline $\begin{array}{c}\text { Tingkat } \\
\text { Kecemasan }\end{array}$ & Jumlah & $\boldsymbol{\%}$ \\
\hline Ringan & 0 & 0 \\
Sedang & 21 & 100 \\
Berat & 0 & 0 \\
\hline Total & $\mathbf{2 1}$ & $\mathbf{1 0 0}$ \\
\hline
\end{tabular}

Tabel 4. Distribusi Responden Berdasarkan Tingkat Kecemasan Klien Setelah Konseling

Tingkat

Kecemasan

Ringan Jumlah Persentase

Sedang

13

61.9

Berat

8

38.1

Total

21

100

Berdasarkan tabel 2. dapat diketahui bahwa dari 21 orang responden risiko tinggi HIV dan AIDS yang tertinggi adalah sex anal tanpa kondom (2) dengan ejakulasi didalam sebanyak 12 orang $(57,14 \%)$.

Berdasarkan tabel 3. didapatkan bahwa tingkat kecemasan sebelum konseling adalah kecemasan sedang dengan jumlah 21 orang (100\%).

Berdasarkan tabel 4. didapatkan bahwa tingkat kecemasan tertinggi setelah konseling adalah kecemasan ringan dengan jumlah 13 orang $(61,9 \%)$, sedangkan kecemasan sedang berjumlah 8 orang $(38,1 \%)$.

Untuk melihat pengaruh pemberian konseling terhadap tingkat kecemasan pada 
klien risiko tinggi hiv dan aids di daerah pariwisata medical center Senggigi dapat dilihat pada tabel 5 . berikut :

Tabel 5. Perbedaan Kecemasan Responden Sebelum dan Sesudah Intervensi Konseling

\begin{tabular}{ccccc}
\hline Kecemasan & $\mathrm{n}$ & Mean & $\begin{array}{c}\text { St. } \\
\text { Deviasi }\end{array}$ & $\begin{array}{c}p \text { - } \\
\text { value }\end{array}$ \\
\hline Pre-Post & 21 & 6,19 & 4,98 & 0,000 \\
\hline
\end{tabular}

Berdasarkan tabel 5. dapat diketahui

bahwa kecemasan yang dirasakan responden sebelum dan sesudah dilakukan konseling, mempunyai perbedaan nilai sebesar 6,19 dengan standar deviasi 4,98. Nilai $p$ value 0,000 menunjukkan bahwa nilai tersebut lebih kecil bila bandingkan nilai alpha $5 \%(0,05)$, artinya terdapat perbedaan kecemasan sebelum dan sesudah konseling, sehingga dapat disimpulkan ada pengaruh konseling spiritual terhadap tingkat kecemasan pada klien risiko tinggi hiv dan aids di daerah pariwisata medical center Senggigi.

\section{PEMBAHASAN}

Hasil analisis univariat menunjukkan bahwa seluruh responden mengalami kecemasan dalam kategori sedang dengan skor yang berbeda. Instrumen yang digunakan dalam penelitian ini adalah kuesioner Hamilton Anxiety Rating Scale (HARS), yang membagi kecemasan menjadi 5 tingkat kecemasan, yaitu tidak cemas, cemas ringan, cemas sedang, cemas berat dan panik. Gejala kecemasan yang dirasakan responden berdasarkan kuesioner HARS dengan hasil konseling pada sesi I yaitu responden mengungkapkan bahwa mereka merasa takut, memiliki firasat buruk, merasa tegang dan gelisah, susah tidur, tidur tidak nyenyak, menurunnya konsentrasi dan minat, serta gejala somatik seperti sakit kepala, nyeri otot, otot tegang, sulit menelan, gemetar, sering BAK, jantung berdebar dan merasa sesak. Ketika seseorang menghadapi masalah yang kemudian menimbulkan konflik, dan membuat orang tersebut mengalami kondisi yang tidak nyaman, maka orang tersebut mengalami stres. Dalam kondisi stres tersebut, akan muncul reaksi-reaksi pada diri seseorang, salah satunya adalah kecemasan. Profesi sebagai pekerja seks juga tak lepas dari resiko terkena aneka penyakit, salah satunya adalah HIV/AIDS yang memang penyebarannya lebih banyak dilakukan melalui hubungan seksual $(17,18)$.
Intervensi keperawatan yang dapat diberikan pada klien yang mengalami kecemasan berdasarkan Nursing Intervetion Classification antara lain konseling Bulechek, G.M., et al. (9). Konseling merupakan proses yang berfokus pada kebutuhan, masalah atau perasaan klien melalui komunikasi aktif dua arah, pertukaran pengalaman, pemberian solusi berdasarkankesepakatan bersama guna menemukan ide untuk meningkatkan ataumendukung koping, pemecahan masalah dan menciptakan hubungan interpersonal yang baik. Salah satu jenis konseling yang dapat diterapkan pada korban gempa adalah konseling spiritual. Penelitian sebelumnya menjelaskan ada pengaruh yang signifikan dari konseling spiritual perawat terhadap tingkat kecemasan pada keluarga pasien yang dirawat diruang ICU RSUD Sleman (8).

Melalui konseling pada sesi 2 responden diberikan kesempatan untuk mengungkapkan solusi-solusi yang bersifat melakukan problem focused coping yang telah dilakukan guna mengatasi rasa cemas yang ada. Hasil konseling menunjukkan bahwa ketika seseorang tidak begitu memikirkan masalah yang sedang dihadapi oleh subyek, berpikir bahwa ada hikmah dari semua masalah yang ada sekarang. Hal ini diungkapkan oleh sebagian besar responden yang mengaku tawakal dengan memasrahkan segalanya kepada Tuhan. Pengalaman tersebut menjadikan mereka semakin dekat kepada Tuhan.

Selanjutnya, responden diberikan pemahaman tentang pentingnya aspek spiritual dalam menghadapi cobaan hidup. Responden diarahkan untuk senantiasa hidup dalam nuansa keimanan kepada Tuhan dan memaknai aktivitasnya dalam kehidupan ini sebagai ibadah kepada Tuhan. Perasaan itu akan menjadikannya kuat dalam menghadapi segala persoalan hidup yang dialami.

Proses penelitian sesi 3 adalah mengkaji tingkat kecemasan yang dialami responden setelah konseling dan didapatkan bahwa hampir seluruh responden mengalami penurunan tingkat kecemasan atau berada dalam kategori ringan. Spiritualitas bermanfaat dalam upaya untuk memecahkan berbagai permasalahan dalam kehidupan. Spiritualitas 
dapat memprioritas-ulangkan tujuan-tujuan (reprioritization of goals). Terlebih lagi, pribadi yang spiritual lebih mudah menyesuaikan diri pada saat menangani kejadian-kejadian traumatis. Mereka pun lebih bisa menemukan makna dalam krisis traumatis dan memperoleh panduan untuk memutuskan hal-hal tepat apa saja yang harus dilakukan $\left({ }^{14}\right)$. Oleh karena itu intervensi konseling dapat mempengaruhi tingkat kecemasan pada klien risiko tinggi hiv dan aids di daerah pariwisata medical center Senggigi, dimana responden awalnya mengalami kecemasan dalam kategori sedang, kemudian turun menjadi kecemasan dalam kategori ringan.

\section{KESIMPULAN}

1. Tingkat kecemasan klien risiko tinggi HIV dan AIDS sebelum konseling di Medical Center Senggigi semuanya adalah dengan kecemasan sedang

2. Tingkat kecemasan klien risiko tinggi HIV dan AIDS setelah menjalani konseling di Medical Center Senggigi tertinggi adalah kecemasan ringan

3. Didapatkan hasil bahwa ada pengaruh yang signifikan antara pemberian konseling dengan tingkat kecemasan klien risiko tinggi HIV dan AIDS di Medical Center Senggigi.

\section{SARAN}

1. Pemberian konseling yang sudah berjalan dengan baik agar tetap dipertahankan dan ditingkatkan dengan mengadakan pelatihan konselor professional secara rutin dan berkesinambungan.

2. Pemberian konseling menunjukan adanya pengaruh yang signifikan dengan tingkat kecemasan klien risiko tinggi HIV dan AIDS sehingga perlu untuk dipertahankan agar kecemasan pasien dapat menurun sehingga dapat menekan angka kejadian bunuh diri.

3. Penelitian ini mengambil lokasi di daerah Senggigi sehingga untuk penelitian selanjutnya perlu untuk mengambil wilayah yang lebih luas sehingga jumlah sampel yang lebih banyak.

\section{DAFTAR PUSTAKA}

UNAIDS. ( 2009). HIV Treatment.

Kementerian Pemberdayaan Perempuan dan perlindungan Anak. (2012). Buku Pedoman HAS. Jakarta: Kementrian
Pemberdayaan perempuan dan perlindungan anak.

Kementrian Kesehatan. (2012). Modul HIV AIDS. Jakarta: Kementrian Kesehatan.

Stuart GW, Sundeen SJ. (1985). Principle and Practice of Psychiatric Nursing. St. Louis Missouri: Mosby Year Book Inc.

Purqoti, D.N. (2017). Pengaruh Pemberian Konseling Spiritual Terhadap Kemampuan Adaptasi Psikologis Pasien Stroke di RSUD Provinsi NTB. Tesis. Universitas Muhammadiyah Jakarta.

Wandira, A., \& Pribadi SB. (2011). Aplication Study of Color Interior of Mother and Child Hospital in Patients Child of Psychology at Hermina Hospital. NCBI.

Yudiati, EA. \& Rahayu, E. (2017). Coping stress dan kecemasan pada orangorang pengidap hiv/aids yang menjalani tes darah dan VCT (Voluntary Counseling Testing). Semarang: Prosiding Temu Ilmiah $\mathrm{X}$ Ikatan Psikologi Perkembangan Indonesia.

Sugiyanto B. (2014). Pengaruh Konseling Spiritual Perawat Terhadap Tingkat Kecemasan pada Keluarga Pasien yang dirawat di Ruang ICU RSUD Sleman Yogyakarta. Naskah Publikasi

Bulechek, G.M., et al. (2013). Nursing Intrventions, Classification (NIC). Six Edition. Mosby: Elsevier.

Kusrini, S.R. (2015). Pengaruh Pendidikan Kesehatan terhadap Kecemasan Remaja Putri Menghadapi Masa

Pubertas. Tesis. Univesitas Gadjah Mada, Yogyakarta.

Budi, A. (2012). Konseling Dan VCT. Jakarta: Salemba Medika.

Lewis. (2007). Medical Surgical Nursing, Assesment and Management of Clinical Problem. Seventh Edition. Volume 2. St. Louis: Missouri. Mosby.Elsevier INC.

Fu'ad, Dayal, \& Fuad. (2015). Uji validitas dan reliabilitas Hamilton Anxiety Rating Scale terhadap kecemasan dan produktivitas pekerja visual inspection 
PT. Widatra Bhakti. Retrieved from: http://library.itn.ac.id/jurnal/index.php /KADO/article/view.

Dewita, Sisri. (2012). Kondisi Psikologis Masyarakat Pasca Bencana. Retrieved from: https://sisridewitayaipsi07.blogspot.co m/2012/04/kondisi-psikologismasyarakat-pasca.html.

Program Studi Ilmu Keperawatan Sekolah Tinggi Ilmu Kesehatan 'Aisyi yahYogyakarta.

Suwarti. (2009). STRATEGI COPING WARIA DALAM MENGHADAPI KECEMASAN TERJANGKIT HIV /AIDS DI PURWOKERTO. PSYCHO IDEA, (1), 35-47.

Yudiati, E. A., \& Rahayu, E. (2016). Hubungan antara coping stres dengan kecemasan pada orang-orang pengidap hiv/aids yang menjalani tes darah dan vct (. Psikodimensia, 15(2), 337-350. 